\title{
Prevalence of Risk Factors for Chronic Non-Communicable Diseases to the National Teaching Hospital "HKM" of Cotonou
}

\author{
Annelie Kerekou-Hode ${ }^{1}$, Stéphane Dismand Houinato ${ }^{2}$, Mylidia Bocovo ${ }^{3}$, \\ Daniel Amoussou-Guenou', François Djrolo \\ ${ }^{1}$ University Clinic of Endocrinology and Metabolic Diseases of Cotonou, University of Abomey-Calavi, Cotonou, Benin \\ ${ }^{2}$ Neurology Unit of Cotonou, University of Abomey-Calavi, Cotonou, Benin \\ ${ }^{3}$ Internal Medicine Unit of Cotonou, University of Abomey-Calavi, Cotonou, Benin \\ Email: kerekouannelie@yahoo.fr
}

Received 25 March 2015; accepted 7 July 2015; published 10 July 2015

Copyright (C) 2015 by authors and Scientific Research Publishing Inc.

This work is licensed under the Creative Commons Attribution International License (CC BY).

http://creativecommons.org/licenses/by/4.0/

c) (i) Open Access

\begin{abstract}
Background: In 2008 Non-communicable diseases (NCDs) were responsible for $63 \%$ of deaths worldwide and $80 \%$ of these deaths occurred in developing countries. Four of them were responsible for more than $\mathbf{8 0 \%}$ of mortality from NCDs, which were cardiovascular diseases, cancers, chronic respiratory diseases, and diabetes. They shared the same risk factors. Objective: To determine the prevalence of NCD risk factors in patients admitted to consult in the outpatient unit of the National Teaching Hospital of Cotonou. Patients and Methods: This was a transversal, descriptive and analytical study which took place from 15 June 2011 to 16 September 2011. It focused on 1000 subjects found after a recruitment of all patients coming to consult during the study period. The collection technique was a questionnaire followed by physical measures (weight, height, blood pressure and waist) and biological measures (fasting glucose and cholesterol). The data were analyzed with the software Epi-3.3.2 info. Results: The mainly prevalent behavioural risk factors were smoking $(10.2 \%)$, alcohol consumption $(60.3 \%)$, insufficient intake of fruits and vegetables $(84.2 \%)$, and physical inactivity $(57.6 \%)$. The prevalent physical risk factors were hypertension $(47.4 \%)$, obesity $(27.5 \%)$, and overweight $(35.3 \%)$. The prevalent biological risk factors were diabetes $(28.5 \%)$, and hypercholesterolemia $(10.4 \%)$. The level of cardiovascular risk was higher than $40 \%$ in 81 people $(8.1 \%)$. Conclusion: This study shows the importance of risk factors for NCDs in outpatient Unit in the National Teaching Hospital of Cotonou.
\end{abstract}

\section{Keywords}

Prevalence, Chronic Non-Communicable Diseases, Risk Factors, Benin

\footnotetext{
"Corresponding author.
}

How to cite this paper: Kerekou-Hode, A., Houinato, S.D., Bocovo, M., Amoussou-Guenou, D. and Djrolo, F. (2015) Prevalence of Risk Factors for Chronic Non-Communicable Diseases to the National Teaching Hospital "HKM" of Cotonou. Journal of Diabetes Mellitus, 5, 155-163. http://dx.doi.org/10.4236/jdm.2015.53019 


\section{Introduction}

For a long time, the whole world and especially developing countries have invested in the fight against infectious diseases (tuberculosis, malaria and HIV/AIDS), maternal and perinatal conditions and malnutrition. Today, we are witnessing the epidemiological transition phenomenon which schematically is a decline of these diseases to chronic non-communicable diseases (NCDs) [1].

Non-communicable diseases are the leading causes of death worldwide, killing more people each year than all other causes combined. Contrary to popular opinion, the available data show that nearly $80 \%$ of deaths from NCDs occur in low- and middle-income countries. Of the 57 million deaths that occurred worldwide in 2008, 36 million deaths were due to non-communicable diseases, mainly including cardiovascular diseases, cancers, diabetes and chronic lung diseases. The combined burden of these diseases is rising faster among low-income countries, populations and communities [2].

This introductory study on NCD risk factors aims to determine the prevalence and to assess cardiovascular risk in hospital in Cotonou.

\section{Background and Study Method}

The study was conducted in the outpatient unit of the National Teaching Hospital of Cotonou that is the reference hospital of Benin. Benin is a West African country, and in 2013 its population was 10.2 million, GDP was 8.307 billion US dollars and the poverty rate was $36 \%$. There is no social security. The outpatient unit of the National Teaching Hospital has four consulting areas: internal medicine and medical oncology, endocrinology and metabolic diseases, neurology, rheumatology.

This was a transversal, descriptive and analytical study which took place from 15 June to 16 September 2011 and involved 1000 patients. Were included, patients aged 15 and over who came to consult during the study period. Were excluded, patients who have not given their approval to participate in the study, pregnant patients, patients unable to answer questions. The minimum sample size (938) was calculated by using the formula of Schwartz. During the study period, we recruited all patients coming to consult with the above mentioned specialists and meeting the inclusion criteria.

The studied variables were socio-demographic (age, sex, level of education, occupation and marital status), behavioral (physical activity, consumption of fruits and vegetables, smoking, consumption alcohol), physical (blood pressure, weight, BMI), biological (blood sugar, cholesterol). We defined regular physical activity by this way: doing at least 30 minutes of physical activity of moderate intensity (eg. hurried walking) for at least 5 days out of 7. Insufficient consumption of fruits and vegetables: lower fruit and vegetable consumption in 5 portions $(400 \mathrm{~g})$ per day. Active smoking was defined as the use of at least one cigarette or cigar or pipe for more than 6 months. Passive smoking was defined by the voluntary or involuntary inhalation of smoke from one or more smokers. Alcoholism has been defined by the consumption of a standard drink equivalent to 10 grams of pure ethanol. The heavy drinking was defined as consumption of 2 standard drinks or more per day for women or consumption of 4 standard drinks or more per day for men. Harmful alcohol consumption was defined as the consumption of 4 standard drinks or more per day for women or consumption of 6 glasses or more per day in humans. High blood pressure (hypertension) was defined by systolic blood pressure (SBP) $\geq 140$ and a diastolic blood pressure (DBP) $\geq 90 \mathrm{mmHg}$. Obesity was defined as BMI $\geq 30 \mathrm{~kg} / \mathrm{m}^{2}$, overweight by BMI $\leq 25<30$ $\mathrm{kg} / \mathrm{m}^{2}$, Abdominal obesity was defined as a waist circumference $>88 \mathrm{~cm}$ in women and $>102$ in humans. We considered diabetic any subject having a fasting glucose $\geq 1.26 \mathrm{~g} / 1$ rechecked at least once, or any subject under anti-diabetic drugs. Hypercholesterolemia was defined by a cholesterol $\geq 2.5 \mathrm{~g} / \mathrm{l}$.

The collection technique was done by a questionnaire. We filled out for each patient the questionnaire on risk factors. At the end of the consultation, we suggested to the patient achieving a fasting blood glucose and cholesterol, and we followed the appointment of control patients to retrieve the results. Laboratory tests were dependent to patients. We also evaluated the cardiovascular risk at 10 years of each subject by using the WHO diagram of prediction of cardiovascular risk for AFR-D region.

The collected data were entered by using Epi-data 3.1 and analyzed with Epi-Info 3.3.2 software. Qualitative variables were described by using percentages and their confidence intervals. Quantitative variables were described by using the average and standard deviation. Comparisons of frequency were made by using the Chi test 2 and the comparisons of average with the test Student. A p-value $\leq 0.05$ was statistically considered significant. 


\section{Results}

Among the 1000 patients included in our study, 444 were male (44.4\%) and 556 women (55.6\%). The sex ratio was 0.79 . The average age of patients was 48,1 years $\pm 14,5$ years.

\subsection{Prevalence of Behavioral Risk Factors}

Smoking prevalence was $10.2 \%(\mathrm{n}=102)(95 \% \mathrm{CI}: 8.3 \%-12.1 \%)$. Among the 444 male subjects, 53 were smokers, a prevalence of $11.9 \%$ against $8.8 \%$ among 556 female subjects. The difference between these two prevalences was not statistically significant $(\mathrm{p}=0.11)$. Smoking prevalence was higher among those aged from 26 to 35 but the difference was not statistically significant $(\mathrm{p}=0.12)$. Smoking prevalence was significantly higher among patients not attending school $(\mathrm{p}=0.03)$. There was no statistically significant difference in terms of occupation and marital status (Table 1).

The prevalence of alcohol consumption was $60.3 \%(n=603)$ with a male predominance $(66.2 \%$ in men and $55.6 \%$ women). The prevalence of harmful alcohol consumption was significantly higher in men than that of women $(\mathrm{p}=0.02)$. There was no statistically significant difference according to age, education, occupation or marital status (Table 1).

The prevalence of alcohol abuse was significantly higher in men than in women $(p=0.05)$. This prevalence was significantly higher among the less educated patients. There was no significant difference in terms of age, occupation or marital status (Table 1).

The prevalence of low fruit and vegetables was $84.2 \%(n=842)$. Among the 444 males, 381 were not consuming enough fruits and vegetables, a prevalence of $85.8 \%$ versus $82.9 \%$ of the 556 female subjects $(p=0.21)$. The prevalence of low fruit and vegetables varied significantly with age $(p=0.02)$ and occupation $(p=0.04)$. The prevalence of consumption of fruit and vegetables failure was higher among the non-schooling and those who had a primary and secondary school level $(\mathrm{p}<0.01)$. There was no statistically significant difference with marital status (Table 1).

The prevalence of physical inactivity was $57.6 \%(\mathrm{n}=576)$. It was $51.8 \%$ in men versus $62.2 \%$ in women $(\mathrm{p}<$ $0.01)$. It varied statistically with age groups $(p=0.01)$, educational level $(p<0.001)$ and occupation $(p<0.001)$. There was no statistically significant difference between marital status (Table 1).

\subsection{Prevalence of Physical and Biological Risk Factors}

Hypertension prevalence was $47.4 \%(n=474)$. Among the 444 males, 203 were hypertensive, a prevalence of $45.7 \%$ and $556 \%$ female subjects, 271 had hypertension, a prevalence of $48.7 \%(\mathrm{p}=0.37)$. The prevalence of hypertension increased significantly with age $(\mathrm{p}<0.001)$ and educational level $(\mathrm{p}=0.01)$. It was significantly lower among single $(\mathrm{p}<0.001)$. The prevalence was significantly higher among the housewife and retired $(\mathrm{p}<$ $0.001)$.

Overweight prevalence was $35.3 \%(\mathrm{n}=353)$. It was $36.5 \%$ in men versus $34.4 \%$ in women with no statistically significant difference. It was higher among patients of 36 to 55 years with a statistically significant difference $(p<0.001)$. The prevalence of overweight was significantly higher among state employees (civil servants) and housewives $(\mathrm{p}<0.001)$, married and unmarried partners $(\mathrm{p}<0.001)$. There was no significant difference in the level of education (Table 2).

Obesity prevalence was $27.5 \%(\mathrm{n}=275)$. It was significantly higher among women $36 \%$ than males $16.9 \%(\mathrm{p}$ $<0.001)$ and in the age group 46 to 55 years $(\mathrm{p}<0.001)$. It was significantly higher among the unemployed, housewives $(\mathrm{p}<0.001)$ as well as divorced $(\mathrm{p}<0.001)$. There was no statistically significant difference between the level of education (Table 2).

Abdominal obesity prevalence was $34.8 \%$. It was significantly higher with women $(51.1 \%)$ than in men (14.4\%). It was significantly higher in the age group of 46 to 65 , in school, and patients with primary level education, among housewives and unemployed, and among the widowed and divorced (Table 2).

The prevalence of diabetes was $28.5 \%(\mathrm{n}=348)$. There was no significant difference between the two sexes. It was significantly higher in the age group 56 to 65 years $(\mathrm{p}<0.001)$ among retirees $(\mathrm{p}<0.001)$ and divorced $(\mathrm{p}<0.001)$ (Table 2).

Among the 1000 subjects investigated, only 405 have performed the test of cholesterol. Hypercholesterolemia was observed in 42 people, a prevalence of $10.4 \%$. The prevalence of hypercholesterolemia was significantly 
Table 1. Distribution of patients based on behavioural risk factors alcoholism.

\begin{tabular}{|c|c|c|c|c|c|c|c|c|c|c|}
\hline \multicolumn{11}{|c|}{ Alcoholism } \\
\hline & Smoking & $\mathbf{p}$ & harmful & $\mathbf{p}$ & Abusive & $\mathbf{p}$ & $F$ and $V^{*}$ & $\mathbf{p}$ & PI & $\mathbf{P}$ \\
\hline Global $(n=1000)$ & $10.2 \%$ & & $1.3 \%$ & & $9.7 \%$ & & $84.2 \%$ & & $57.6 \%$ & \\
\hline Sex & & 0.11 & & 0.02 & & 0.05 & & 0.21 & & $<0.01$ \\
\hline Male $(n=444)$ & $11.9 \%$ & & $2.3 \%$ & & $7.7 \%$ & & $85.8 \%$ & & $51.8 \%$ & \\
\hline Female $(\mathrm{n}=556)$ & $8.8 \%$ & & $0.5 \%$ & & $11.3 \%$ & & $82.9 \%$ & & $62.2 \%$ & \\
\hline Age (years) & & 0.12 & & 1 & & 0.41 & & 0.02 & & 0.01 \\
\hline $15-25(\mathrm{n}=83)$ & $2.4 \%$ & & $1.2 \%$ & & 0.06 & & $91.6 \%$ & & $48.2 \%$ & \\
\hline $26-35(\mathrm{n}=139)$ & $12.9 \%$ & & $1.4 \%$ & & $7.9 \%$ & & $81.3 \%$ & & $52.5 \%$ & \\
\hline $36-45(n=183)$ & $9.8 \%$ & & $1.1 \%$ & & $9.8 \%$ & & $90.7 \%$ & & $63.9 \%$ & \\
\hline $46-55(n=252)$ & $11.9 \%$ & & $1.6 \%$ & & $12.3 \%$ & & $82.5 \%$ & & 0.52 & \\
\hline $56-65(n=211)$ & 0.1 & & $1.4 \%$ & & $10.9 \%$ & & $80.1 \%$ & & $62.6 \%$ & \\
\hline$>65(\mathrm{n}=132)$ & $9.8 \%$ & & $0.8 \%$ & & $6.8 \%$ & & $83.3 \%$ & & $62.9 \%$ & \\
\hline Level of education & & 0.03 & & 0.6 & & 0.05 & & $<0.01$ & & $<0.001$ \\
\hline Not schooling $(\mathrm{n}=83)$ & $19.3 \%$ & & $1.2 \%$ & & $7.2 \%$ & & $92.8 \%$ & & $63.9 \%$ & \\
\hline Primary $(n=200)$ & $10.5 \%$ & & 0.02 & & 0.13 & & $87.5 \%$ & & $70.5 \%$ & \\
\hline Secondary $(n=442)$ & $9.5 \%$ & & $0.9 \%$ & & $10.9 \%$ & & $85.1 \%$ & & $56.3 \%$ & \\
\hline higher $(n=275)$ & $8.4 \%$ & & $1.5 \%$ & & $6.2 \%$ & & $77.8 \%$ & & $48.4 \%$ & \\
\hline Occupation & & 0.22 & & 0.9 & & 0.54 & & 0.04 & & $<0.001$ \\
\hline Civil servant $(\mathrm{n}=286)$ & $10.8 \%$ & & $1.4 \%$ & & $9.8 \%$ & & $81.8 \%$ & & $45.5 \%$ & \\
\hline private $(\mathrm{n}=81)$ & $11.1 \%$ & & $1.2 \%$ & & $7.4 \%$ & & $77.8 \%$ & & $61.7 \%$ & \\
\hline Independent $(\mathrm{n}=301)$ & 0.12 & & 0.02 & & 0.12 & & $88.4 \%$ & & $67.4 \%$ & \\
\hline Learner $^{*}(\mathrm{n}=79)$ & $2.5 \%$ & & 0 & & $5.1 \%$ & & $91.1 \%$ & & $45.6 \%$ & \\
\hline Housewife $(n=67)$ & $11.9 \%$ & & 0 & & $11.9 \%$ & & $79.1 \%$ & & $68.7 \%$ & \\
\hline Unemployed $(\mathrm{n}=4)$ & 0 & & 0 & & 0 & & 1 & & 1 & \\
\hline Retirees $(n=182)$ & $8.8 \%$ & & $1.1 \%$ & & $8.2 \%$ & & $82.4 \%$ & & $58.8 \%$ & \\
\hline Marital status & & 0.09 & & 0.67 & & 0.86 & & 0.71 & & 0.18 \\
\hline Single $(n=149)$ & $5.4 \%$ & & $0.7 \%$ & & $7.4 \%$ & & $86.6 \%$ & & $51.7 \%$ & \\
\hline Married $(n=653)$ & $10.3 \%$ & & $1.4 \%$ & & $10.1 \%$ & & $83.5 \%$ & & $58.8 \%$ & \\
\hline Divorced $(n=12)$ & $16.7 \%$ & & 0 & & $8.3 \%$ & & 0.75 & & $41.7 \%$ & \\
\hline Widower $(\mathrm{n}=58)$ & $15.5 \%$ & & 0 & & $8.6 \%$ & & $84.5 \%$ & & $67.2 \%$ & \\
\hline Concubine $(\mathrm{n}=128)$ & $12.5 \%$ & & $2.3 \%$ & & $10.9 \%$ & & $85.9 \%$ & & $55.5 \%$ & \\
\hline
\end{tabular}

Learner $=$ student/apprentice; $\mathrm{PI}=$ Physical inactivity; $\mathrm{F}$ and $\mathrm{V}=$ low fruit and vegetable.

higher in women $(\mathrm{p}<0.001)$. It significantly increased with age $(\mathrm{p}<0.01)$. It was significantly higher with divorced. It had no significant difference in the level of education (Table 3 ).

The cardiovascular risk was less than $10 \%$ in $66 \%$ of patients, but $8 \%$ of them had a risk greater than $40 \%$ (Figure 1). Cardiovascular risk was significantly higher among patients with abdominal obesity, hypertension and diabetes (Table 4). 


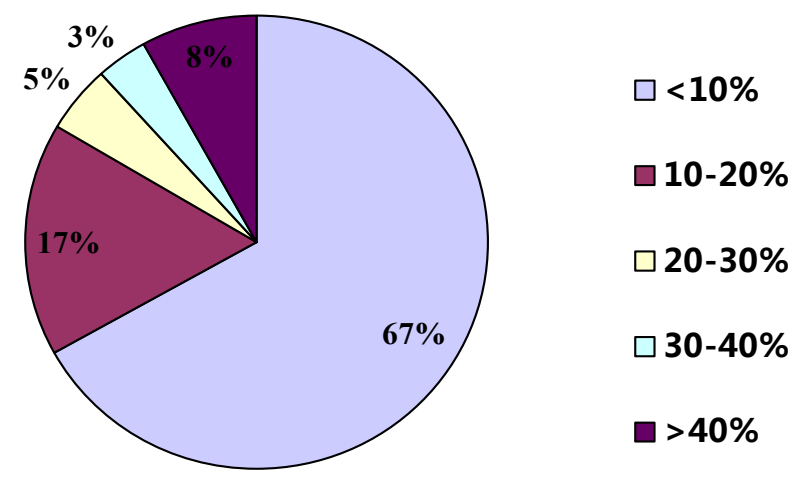

Figure 1. Distribution of the patients according to their level of cardiovascular risk.

Table 2. Distribution of patients based on physical and biological risk factors.

\begin{tabular}{|c|c|c|c|c|c|c|c|c|c|c|}
\hline & HT & $\mathbf{p}$ & Overweight & $\mathbf{p}$ & Obesity & $\mathbf{p}$ & Abdominal obesity & $\mathbf{p}$ & Diabetes & $\mathbf{p}$ \\
\hline Global $(n=1000)$ & $47.4 \%$ & & $35.3 \%$ & & $27.5 \%$ & & $34.8 \%$ & & $28.5 \%$ & \\
\hline Sex & & 0.37 & & 0.52 & & $<0.001$ & & $<0.001$ & & 0.67 \\
\hline Male $(n=444)$ & $45.7 \%$ & & $36.5 \%$ & & $16.9 \%$ & & $14.4 \%$ & & $27.7 \%$ & \\
\hline Female $(\mathrm{n}=556)$ & $48.7 \%$ & & $34.4 \%$ & & $36.00 \%$ & & $51.1 \%$ & & $29.1 \%$ & \\
\hline Age (years) & & $<0.001$ & & $<0.001$ & & $<0.001$ & & $<0.001$ & & $<0.001$ \\
\hline $15-25(\mathrm{n}=83)$ & $4.8 \%$ & & $12.1 \%$ & & $4.8 \%$ & & $6.00 \%$ & & $10.8 \%$ & \\
\hline $26-35(n=129)$ & $20.1 \%$ & & $27.3 \%$ & & $20.1 \%$ & & $26.6 \%$ & & $19.4 \%$ & \\
\hline $36-45(n=183)$ & $39.3 \%$ & & $41.5 \%$ & & $31.7 \%$ & & $37.2 \%$ & & $20.2 \%$ & \\
\hline $46-55(n=252)$ & $60.3 \%$ & & $41.3 \%$ & & $35.3 \%$ & & $44.4 \%$ & & $33.3 \%$ & \\
\hline $56-65(n=211)$ & $62.6 \%$ & & $38.4 \%$ & & $28.9 \%$ & & $40.3 \%$ & & $41.2 \%$ & \\
\hline$>65(\mathrm{n}=132)$ & $65.2 \%$ & & $33.3 \%$ & & $26.5 \%$ & & $31.00 \%$ & & $31.1 \%$ & \\
\hline Level of education & & $<0.01$ & & 1 & & 0.16 & & 0.02 & & 0.15 \\
\hline $\begin{array}{l}\text { Non schooling }(\mathrm{n}= \\
83)\end{array}$ & $38.9 \%$ & & $34.9 \%$ & & $26.5 \%$ & & $43.4 \%$ & & $32.5 \%$ & \\
\hline Primary $(n=200)$ & $47.2 \%$ & & $35.5 \%$ & & $33.00 \%$ & & $40.5 \%$ & & $24.5 \%$ & \\
\hline Secondary $(n=442)$ & $52.5 \%$ & & $35.5 \%$ & & $27.6 \%$ & & $34.2 \%$ & & $31.5 \%$ & \\
\hline Higher $(\mathrm{n}=275)$ & $59.00 \%$ & & $34.9 \%$ & & $23.6 \%$ & & $29.1 \%$ & & $25.5 \%$ & \\
\hline Occupation & & $<0.001$ & & $<0.001$ & & $<0.001$ & & $<0.001$ & & $<0.001$ \\
\hline $\begin{array}{c}\text { Civil servant }(\mathrm{n}= \\
286)\end{array}$ & $45.5 \%$ & & $42.7 \%$ & & $23.8 \%$ & & $32.2 \%$ & & $26.9 \%$ & \\
\hline $\begin{array}{l}\text { Private worker }(\mathrm{n}= \\
81)\end{array}$ & $32.1 \%$ & & $30.9 \%$ & & $29.6 \%$ & & $36.7 \%$ & & $26.6 \%$ & \\
\hline Independent $(\mathrm{n}=301)$ & $49.5 \%$ & & $33.2 \%$ & & $33.2 \%$ & & $40.5 \%$ & & $26.9 \%$ & \\
\hline Learner $(\mathrm{n}=79)$ & $7.6 \%$ & & $15.2 \%$ & & $3.8 \%$ & & $3.8 \%$ & & $12.7 \%$ & \\
\hline Housewife $(n=67)$ & $58.2 \%$ & & $44.8 \%$ & & $40.3 \%$ & & $58.2 \%$ & & $31.3 \%$ & \\
\hline Unemployed $(\mathrm{n}=4)$ & $25.00 \%$ & & $25.00 \%$ & & $50.00 \%$ & & $50.00 \%$ & & $0.00 \%$ & \\
\hline Retirees $(\mathrm{n}=182)$ & $67.00 \%$ & & $34.6 \%$ & & $28.00 \%$ & & $33.5 \%$ & & $41.2 \%$ & \\
\hline Marital status & & $<0.001$ & & $<0.001$ & & $<0.001$ & & $<0.001$ & & $<0.001$ \\
\hline Single $(n=149)$ & $18.1 \%$ & & $18.8 \%$ & & $10.7 \%$ & & $11.4 \%$ & & $16.1 \%$ & \\
\hline Married $(n=653)$ & $53.4 \%$ & & $39.5 \%$ & & $30.8 \%$ & & $38.3 \%$ & & $30.3 \%$ & \\
\hline Divorced $(\mathrm{n}=12)$ & $50.00 \%$ & & $25 \%$ & & $50.00 \%$ & & $50.00 \%$ & & $66.7 \%$ & \\
\hline Widower $(\mathrm{n}=58)$ & $58.6 \%$ & & $29.3 \%$ & & $36.2 \%$ & & $53.4 \%$ & & $43.1 \%$ & \\
\hline Concubine $(\mathrm{n}=128)$ & $45.3 \%$ & & $36.5 \%$ & & $24.2 \%$ & & $34.4 \%$ & & $23.4 \%$ & \\
\hline
\end{tabular}

$\mathrm{HT}=$ Hypertension. 
Table 3. Distribution of patients according to biological risk factors.

\begin{tabular}{|c|c|c|}
\hline & Hypercholesterolemia & $\mathrm{p}$ \\
\hline Global $(n=405)$ & $10.4 \%$ & \\
\hline Sex & & $<0.001$ \\
\hline Male $(n=178)$ & $0.6 \%$ & \\
\hline Female $(\mathrm{n}=227)$ & $11.00 \%$ & \\
\hline Age (years) & & $<0.01$ \\
\hline $26-35(n=9)$ & $2.3 \%$ & \\
\hline $36-45(n=17)$ & $4.2 \%$ & \\
\hline $46-55(n=53)$ & $13.00 \%$ & \\
\hline $56-65(\mathrm{n}=57)$ & $14.00 \%$ & \\
\hline$>65(\mathrm{n}=69)$ & $17.00 \%$ & \\
\hline Level of education & & 0.91 \\
\hline Non schooling $(\mathrm{n}=29)$ & $6.9 \%$ & \\
\hline Primary $(\mathrm{n}=70)$ & $10.00 \%$ & \\
\hline Secondary $(\mathrm{n}=198)$ & $10.1 \%$ & \\
\hline Higher $(\mathrm{n}=108)$ & $12.00 \%$ & \\
\hline Occupation & & 0.34 \\
\hline Civil servant $(\mathrm{n}=118)$ & $11.00 \%$ & \\
\hline Private worker $(\mathrm{n}=35)$ & $5.7 \%$ & \\
\hline Independent $(\mathrm{n}=115)$ & $10.4 \%$ & \\
\hline Student $(\mathrm{n}=27)$ & $0.00 \%$ & \\
\hline Housewife $(\mathrm{n}=26)$ & $11.5 \%$ & \\
\hline Retiree $(\mathrm{n}=84)$ & $14.3 \%$ & \\
\hline Marital status & & $<0.01$ \\
\hline Single $(n=11)$ & $2.6 \%$ & \\
\hline Married $(n=43)$ & $10.5 \%$ & \\
\hline Divorced $(n=116)$ & $28.6 \%$ & \\
\hline Widower $(\mathrm{n}=54)$ & $13.3 \%$ & \\
\hline Concubine $(n=47)$ & $11.5 \%$ & \\
\hline
\end{tabular}

\section{Discussion}

This study allowed us to evaluate the prevalence of risk factor of Non Communicable Diseases in hospitals. Smoking prevalence in our sample was 10.2\%. It is lower than that of Kouassi in Abidjan population 36.5\% in 2009 [3] and Hounkpatin in Lome 25\% in 2007 [4]. Our prevalence is similar to that of Tesfaye et al. 11\%, according to an investigation conducted in Addis Ababa in Ethiopia in 2006 [5] For Awoke et al. 2014 smoking prevalence varied from $7.3 \%$ to $8.5 \%$ in Addis Ababa [2].

The prevalence of alcohol consumption was $60.3 \%$. This prevalence was similar to that found in South Africa $65.5 \%$ [6], It was less than that of Cameroon [7] which was $85 \%$ in urban areas. Our prevalence was high compared to the 54\% prevalence of alcoholism in the central and southern Nigeria in 2005 [8]. 
Table 4. Relationship between cardiovascular risk and some risk factors.

\begin{tabular}{|c|c|c|c|c|c|c|}
\hline & $<10 \%$ & $10 \%-20 \%$ & $20 \%-30 \%$ & $30 \%-40 \%$ & $>40 \%$ & $\mathrm{p}$ \\
\hline \multicolumn{7}{|l|}{ Smoking } \\
\hline Yes $(n=102)$ & $68.6 \%$ & $13.7 \%$ & $3.9 \%$ & $3.9 \%$ & $9.8 \%$ & 0.90 \\
\hline No $(\mathrm{n}=898)$ & $66.7 \%$ & $16.9 \%$ & $4.9 \%$ & $3.6 \%$ & $7.9 \%$ & \\
\hline \multicolumn{7}{|l|}{ Alcoholism } \\
\hline Yes $(n=603)$ & $65.8 \%$ & $16.9 \%$ & $4.3 \%$ & $3.6 \%$ & $9.3 \%$ & 0.78 \\
\hline No $(n=397)$ & $68.5 \%$ & $16.1 \%$ & $5.5 \%$ & $3.5 \%$ & $6.3 \%$ & \\
\hline \multicolumn{7}{|c|}{ Physical activity } \\
\hline No $(\mathrm{n}=576)$ & $64.8 \%$ & $17.00 \%$ & $4.3 \%$ & $4.5 \%$ & $9.4 \%$ & \\
\hline Irregular $(\mathrm{n}=313)$ & $71.1 \%$ & $15.9 \%$ & $5.1 \%$ & $2.5 \%$ & $5.4 \%$ & 0.28 \\
\hline Regular $(\mathrm{n}=111)$ & $66.1 \%$ & $16.5 \%$ & $6.4 \%$ & $1.8 \%$ & $9.2 \%$ & \\
\hline \multicolumn{7}{|c|}{ Abdominal obesity } \\
\hline Yes $(\mathrm{n}=348)$ & $50.6 \%$ & $24.7 \%$ & $6.3 \%$ & $5.7 \%$ & $12.6 \%$ & $<0.001$ \\
\hline No $(n=652)$ & $75.6 \%$ & $12.3 \%$ & $4.00 \%$ & $2.5 \%$ & $5.7 \%$ & \\
\hline \multicolumn{7}{|l|}{ HT } \\
\hline Yes $(n=474)$ & $37.6 \%$ & $29.5 \%$ & $8.2 \%$ & $7.6 \%$ & $17.1 \%$ & $<0.001$ \\
\hline No $(\mathrm{n}=526)$ & $93.3 \%$ & $4.9 \%$ & $1.7 \%$ & 0 & 0 & \\
\hline \multicolumn{7}{|l|}{ Diabetes } \\
\hline Yes $(\mathrm{n}=285)$ & $47.7 \%$ & $22.5 \%$ & $10.5 \%$ & $7.00 \%$ & $12.3 \%$ & $<0.001$ \\
\hline No $(n=715)$ & $74.5 \%$ & $14.3 \%$ & $2.5 \%$ & $2.2 \%$ & $6.4 \%$ & \\
\hline
\end{tabular}

The prevalence of nutritional imbalance by fruit and vegetable consumption failure was $84.2 \%$. It was close to that of AR et al. Gbary in Benin in 2011 in the general population which was about 80\% [9].

According to $\mathrm{WHO}, 60 \%$ of the world population fail to maintain activity at recommended levels to induce health benefits [10]. This prevalence was close to $57.6 \%$ found in our study. The lifestyle Westernization of the African urban population can explain this prevalence. A lower prevalence $43.30 \%$ was found by Seck et al. according to a study in Senegal [11]. The prevalence of hypertension was $47.4 \%$ or $45.70 \%$ of men and $48.70 \%$ women. This prevalence was higher than that found in the general population, $27.9 \%$ in Benin in 2008 [9] 36.7\% in Lome in 2011 [12], 34.5\% to Brazzaville in 2006 [13]. This high prevalence can be explained in part by the study population which was in hospital among which $77.8 \%$ had more than 35 years. And secondly the prevalence of hypertension increases with age [14]. Outside Africa, MONA LISA study in France had found $47 \%$ of men and 35\% women [15]; a larger study across Europe in 2006 had found a higher prevalence of $44 \%$ in 2006 [16]. Obesity is now present in all countries in the world. Its prevalence particularly high in some industrialized countries is also increasing in developing countries. The prevalence of $27.5 \%$ was much higher than that of West African populations estimated to $10 \%$ [17]. However, a higher prevalence $32.9 \%$ was found in outpatient unit in Lome by Pessinaba et al. [18] Also, a similar prevalence was 27.7\% found in Tunisia in 1996 [19]. Outside of Africa, the prevalence is also similar to that observed in Kosovo $32.7 \%$ in subjects aged 30 to 83 years [20]. As overweight, its prevalence was 35.3\%. It is similar to that found in 2008 in Tlemcen (Algeria), which was 32\% [21]. It did not vary significantly by gender. Several studies in the continent have reported a prevalence of overweight in women [22] [23]. On the contrary, Vernay et al. noted a prevalence of overweight in men [24] in French. Our study reported a prevalence of $34.8 \%$ of abdominal obesity with a female predominance $51.1 \%$ versus $14.4 \%$. The same trends were found by other authors Ghannem et al. [19]. Other studies in Africa showed $10.2 \%$ in Tunisia [19]; 10.4\% in Senegal [25]. 
The prevalence of hypercholesterolemia was $10.4 \%$. Through Africa and the world the prevalence values of hypercholesterolemia differ significantly. In 2007, 33.4\% were obtained in Senegal; 6.3\% in Algeria [26].

\section{Conclusion}

It was apparent from our study, a sedentary lifestyle of Cotonou population especially among women, a low consumption of fruit and vegetable especially among the less educated population. This passiveveness was probably the cause of overweight and obesity observed especially among employees in the public service and married people. The prevalence of hypertension increased progressively with age while the prevalence of diabetes was higher among the population aged from 56 to 65 and among the divorced. The prevalence of hypercholesterolemia increased with age among the divorced. There was a high prevalence of behavioral physical and biological risk factors; however, cardiovascular risk remained low in most of the population. However, it was more important among patients with abdominal obesity, hypertension and diabetes.

\section{Acknowledgements}

Djossou Alfred: translator; Agossou Alain: computer scientist; Houngbegnon Parfait: statistician.

\section{Conflict of Interest}

The authors say have no conflict of interest.

\section{References}

[1] Foucard, L. (2007) Epidemiological Transition and Development: Is the Increase in Non-Communicable Diseases Inevitable? Medecine Tropicale, 67, 543-544.

[2] Misganaw, A., Mariam, D.H., Ali, A. and Araya, T. (2014) Epidemiology of Major Non-Communicable Diseases in Ethiopia: A Systematic Review. Journal of Health, Population and Nutrition, 32, 1-13.

[3] Kouassi, B., Kpebo, O.D., Horo, K., N'Gom, A., Godé, C., Ahui, B., Koffi, N. and Aka-Danguy, E. (2010) Smoking and Educational Status in Africans. Revue des Maladies Respiratoires, 27, 226-231. http://dx.doi.org/10.1016/j.rmr.2010.01.008

[4] Hounkpati, A.T.J., Djagadou, K.A., Balogou, K.A. and Tidjani, O. (2007) Smoking among Journalists in the Private and Public Media in Togo. Revue des Maladies Respiratoires, 24, 831-843. http://dx.doi.org/10.1016/S0761-8425(07)91385-6

[5] Tesfaye, F., Byass, P., Wall, S., Berhane, Y. and Bonita, R. (2008) Association of Smoking and Khat (Catha edulis Forsk) Use with High Blood Pressure among Adults in Addis Ababa, Ethiopia, 2006. Preventing Chronic Disease, 5, A89.

[6] Gossage, J.P., Snell, C., Parry, C.D., Marais, A.S., Barnard, R., de Vries, M., Blankenship, J., Seedat, S., Hasken, J.M. and May, P.A. (2014) Alcohol Use, Working Conditions, Job Benefits, and the Legacy of the "Dop" System among Farm Workers in the Western Cape Province, South Africa: Hope Despite High Levels of Risky Drinking. International Journal of Environmental Research and Public Health, 11, 7406-7424.

[7] Kengne, A.P., Awah, P., Fezeu, L. and Mbanya, J.C. (2007) The Burden of High Blood Pressure and Related Risk Factors in Urban Sub-Saharan Africa: Evidences from Douala in Cameroon. African Health Sciences, 7, 38-44.

[8] Obot, I.S. (2007) Nigeria: Alcohol and Society Today. Addiction, 102, 519-522. http://dx.doi.org/10.1111/j.1360-0443.2006.01619.x

[9] Houinato, D.S.G.A., Houehanou, Y.C., Djrolo, F., Amoussou, M., Segnon-Agueh, J., Kpozehouen, A. and Salamon, R. (2012) Prevalence of Hypertension and Associated Risk Factors in Benin. Revue d'Épidémiologie et de Santé Publique, 60, 95-102. http://dx.doi.org/10.1016/j.respe.2011.09.010

[10] Waxman, A. (2004) World Health Assembly. WHO Global Strategy on Diet, Physical Activity and Health. Food Nutr Bull., 25, 292-302.

[11] Seck, S.M., Guéye, S., Tamba, K. and Ba, I. (2013) Prevalence of Chronic Cardiovascular and Metabolic Diseases in Senegalese Workers: A Cross-Sectional Study, 2010. Preventing Chronic Disease, 10, Article ID: 110339. http://dx.doi.org/10.5888/pcd10.110339

[12] Yayehd, K., Damorou, F., Akakpo, R., Tchérou, T., N’Da, N.W., Pessinaba, S., Belle, L. and Johnson, A. (2013) Prévalence de l'hypertension artérielle et description de ses facteurs de risque à Lomé (Togo): Résultats d'un dépistage 
réalisé dans la population générale en mai 2011. Annales de Cardiologie et d'Angéiologie, 62, 43-50. http://dx.doi.org/10.1016/j.ancard.2012.09.006

[13] Gombet, T.H., Kimbally-Kaky, G., Ikama, M.S. and Ellenga Mbolla, B.F. (2007) Hypertension artérielle et autres facteurs de risque cardiovasculaires en milieu professionnel Brazzavillois. Médecine d'Afrique Noire, 54, 545-548.

[14] Addo, J., Amoah, A.G. and Koram, K.A. (2006) The Changing Patterns of Hypertension in Ghana: A Study of Four Rural Communities in the Ga District. Ethnicity Disease, 16, 894-899.

[15] Wagner, A., Sadoun, A., Dallongeville, J., Ferrières, J., Amouyel, P., Ruidavets, J.B. and Arveiler, D. (2011) High Blood Pressure Prevalence and Control in a Middle-Aged French Population and Their Associated Factors: The MONA LISA Study. Journal of Hypertension, 29, 43-50. http://dx.doi.org/10.1097/HJH.0b013e32833f9c4d

[16] Hajjar, I., Kotchen, J.M. and Kotchen, T.A. (2006) Hypertension: Trends in Prevalence, Incidence, and Control. Annual Review of Public Health, 27, 465-490. http://dx.doi.org/10.1146/annurev.publhealth.27.021405.102132

[17] Abubakari, A.R., Lauder, W., Agyemang, C., Jones, M., Kirk, A. and Bhopal, R.S. (2008) Prevalence and Time Trends in Obesity among Adult West African Populations: A Meta-Analysis. Obesity Reviews, 9, 297-311. http://dx.doi.org/10.1111/j.1467-789x.2007.00462.x

[18] Pessinaba, S., Yayehd, K., Pio, M., Baragou, R., Afassinou, Y., Tchérou, T. and Damorou, F. (2012) Obesity in Cardiology Consultation in Lome: Prevalence and Risk Factors Associated with Cardiovascular Disease- Study in 1200 Patients. Pan African Medical Journal, 12, 99.

[19] Ghannem, H. and Hadj Fredj, A. (1999) Eating Habits and Cardiovascular Risk Factors. Epidemiologic Study of the Tunisian Sahel. Presse Médicale, 28, 1005-1008.

[20] Soualem, A., Ahami, A.O.T. and Aboussaleh, Y. (2006) Obesity and Associated Factors in Albanese Adults of Former Yugoslavia. Antropo, 12, 35-41.

[21] Yahia-Berrouiguet, A., Benyoucef, M., Meguenni, K. and Brouri, M. (2009) Enquête sur la prévalence des facteurs de risque de maladies cardiovasculaires à Tlemcen (Algérie). Médecine des Maladies Métaboliques, 3, 313-319. http://dx.doi.org/10.1016/S1957-2557(09)74761-3

[22] Siminialayi, I.M., Emem-Chioma, P.C. and Dapper, D.V. (2008) The Prevalence of Obesity as Indicated by BMI and Waist Circumference among Nigerian Adults Attending Family Medicine Clinics as Outpatients in Rivers State. Nigerian Journal of Medicine, 17, 340-345. http://dx.doi.org/10.4314/njm.v17i3.37407

[23] Kamadjeu, R.M., Edward, R., Atanga, J.S., Kiawi, E.C., Unwin, N. and Mbanya, J.C. (2006) Anthropometry Measures and Prevalence of Obesity in the Urban Adult Population of Cameroon: An Update from the Cameroon Burden of Diabetes Baseline Survey. BMC Public Health, 6, 228. http://dx.doi.org/10.1186/1471-2458-6-228

[24] Vernay, M., Malon, A., Oleko, A., Salanave, B., Roudier, C., Szego, E., Deschamps, V., Hercberg, S. and Castetbon, K. (2009) Association of Socioeconomic Status with Overall Overweight and Central Obesity in Men and Women: The French Nutrition and Health Survey 2006. BMC Public Health, 2, 215. http://dx.doi.org/10.1186/1471-2458-9-215

[25] Mbaye, M.N., Niang, K., Sarr, A., Mbaye, A., Diedhiou, D., Ndao, M.D., Kane, A.D., Pessinaba, S., Diack, B., Kane, M., Ka-Cissé, M.S., Diao, M., Diop, S.N. and Kane, A. (2011) Aspects épidémiologiques du diabète au Sénégal: Résultats d'une enquête sur les facteurs de risque cardiovasculaire dans la ville de Saint-Louis. Médecine des Maladies Métaboliques, 5, 659-664. http://dx.doi.org/10.1016/S1957-2557(11)70343-1

[26] Latifa, B.H. and Kaouel, M. (2007) Cardiovascular Risk Factors in Tlemcen (Algeria). Sante, 17, 153-158.

\section{Abbreviations}

NCD: Non-Communicable Diseases

BMI: Body Mass Index

GDP: Gross Domestic Product

WHO: World Health Organization

CI: confidence interval

AFR-D: Africa region D 